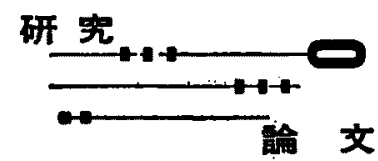

\title{
625. 放射性廃棄物地中処分場の立地要件
}

\author{
井上頼 輝*, 森 澤 真 輔*
}

\author{
（1975年 10月27日 受理）
}

Land Requirement for a Radioactive Waste Disposal Yard

By Yoriteru INOUE and Shinsuke MORISAWA

\begin{abstract}
Land requirement for a radioactive waste disposal site was discussed for keeping a radiological safety of public citizen, which might be caused by the buried wastes through radioactive contamination of water and soil around the disposal yard in a nuclear facility. Two-dimensional transportation diffusion equation, which was used for estimating a ${ }^{\circ 0} \mathrm{Sr}$ distribution in a saturated zone around the waste disposal yard, was analyzed numerically with an aid of high speed digital computer. Those environmental parameters such as velocity of groundwater, diffusion coefficient, equilibrium distribution factor of ${ }^{80} \mathrm{Sr}$ and so on were assumed to be given at the nuclear site through a preliminary site survey.

Direct drinking of groundwater and intake of vegetables cultivated by using a groundwater were assumed as major intake routes of ${ }^{80} \mathrm{Sr}$, which was leaked from buried wastes, and two types of land use restriction area were proposed. The first restriction area, where all kind of groundwater use was to be forbidden, were set around the disposal yard for making sure not to have internal irradiation dose caused by the wastes more than dose limit for the public. The second restriction area was set around the first restriction area and was required not to use groundwater for irrigation.
\end{abstract}

KEYWORDS: radioactive wastes, underground disposal, strontium 90, land requirement, numerical analysis, diffusion equation, land use, radionuclide migration, safety, radiation protection, internal irradiation, dose limit, nuclear facility

\section{1.はじめに}

放射性癉率物の保管廃育場あるいは地中処分場を立 地させる場合には，廃亲物中に含まれる放射性物質が 地中に漏出しても，周辺住民が著しい放射線障害を受 けることがないように所定の広さの教地を礶保すべき であると考元る。原子力発電所の立地汇際しては，す で居住制限区域，居住禁止区域等の土地利用の制的 が課せられて和りこうした区域の設定方法について るすで一応の考方方が提示されている(い。特に，廃 菓物の地中処分場に执いては，放射性核種の地中での 移動速度は極めて遅いため，このような土地利用の制 限区域を合理的に設定することによって，潜在的な放 射線障害の程度を著しく改善できることが陚算によっ て示されている(2)。
本報では，放射性廃菄物の地中処分場を立地させる 場合に，処分場周辺の住民が限度以上の放射線障害を 受计ないために必要な処分場敷地の広さについて検討 乙, 処分場敷地の広さの決定方法, 土地利用制限区域 の設定方法について提案する。さらに，これらの土地 利用の制限区域が処分場周辺の自然環境因子の変化に よってどのよらに変化するかを明らかにする。放射性 廃棄物の地中処分に伴って生ずる地圈・水圈環境の污 染に上り人体が受汁るであるう放射線障害を，限度以 下に維持するために䧹率物処分場が有すべき最小の㪚 地面皘を，ここでは立地要件と呼ぶことにする。

* 京都大学工学部衛生工学教室 (Dept. of Sanitary Eng., Kyoto Univ.) 


\section{II . 放射性核種の地下水中での分布}

放射性廃棄物の地中処分場で処分された廃率物から 地中に漏出した放射性核種は，通気層を移動して地下 水層に達する。さらに，放射性核種は地下水屬を移動 して，ついには人の生活環境に出現すると考えられ る。ここでは，人による放射性核畽の摄取は，地下水 の直接领用の経路と，地下水を灌溉用水に用いて裁培 した贯産物を摄取することによる経路とが主であると 考えて，これら2つの経路による人体の内部被懪につ いて険討する。地中処分された㾳栾物からの空間散乱 放射線による外部被曝についての检討は別の機会に譲 る。

本研究で地中処分場の立地要件を検討するために想 定した敷地を Fig.1 亿示す。図中の位置 A, B, C, D は当該位直において放射性核種が地中に漏出した場合 を想定し，計算によって推定された人体の内部被曝線 量が極小になる位置である(3)。潜在的内部被曝線量の 推定值は位置Aか゚最小で，位圆 B, C, D の順に大きく なる。ここでは位固Aを原子炉等の原子力施設の立地 位唐にあてるとして，廃棄物の処分場 $(100 \mathrm{~m} \times 100 \mathrm{~m}$; 面積 10,000 $\mathrm{m}^{2}$ )を位度Bに立地させるものとする。
Fig. 1 の数地について想定した地下水の等水位線図を Fig. 2 K，敷地の特性值をFig. 3 に示す。數地内の各 特性值は, 數地を覆う 1 辺 $10 \mathrm{~m}$ の正方形格子網の格子 点における値で代表するすのとする。

\section{1. 基礎式}

放射性核種の地下水中での移動を記述する基礎式と して, 次の 2 次元非定常輸送拉散方程式を用いる。す なわら,

$$
\begin{aligned}
\frac{\partial C}{\partial t}+\frac{1-f}{f} \rho \frac{\partial q}{\partial t}= & \frac{\partial}{\partial x}\left(D_{i} \frac{\partial C}{\partial x}\right)+\frac{\partial}{\partial y}\left(D_{y} \frac{\partial C}{\partial y}\right) \\
& -\frac{\partial}{\partial x}\left(v_{x} C\right)-\frac{\partial}{\partial y}\left(v_{y} C\right) \\
& -\lambda\left\{C+\frac{1-f}{f} \rho q\right\} \quad \text { (1) }
\end{aligned}
$$

一方，放射性核種の土譬との反応を記述する式とし ては次式を用いる。

$$
q=k_{a} C
$$

$こ こ に, C, q$ : 故射性核種のおの地下水中. 土塂中濃度

$D_{x}, D_{y}:$ おのおの地下水中での放射性 核種の拡散係数

$v_{s}, v_{v}:$ 打のおのx,y方向の地下水流速 $\lambda:$ 故射性核種の崩㙲定数

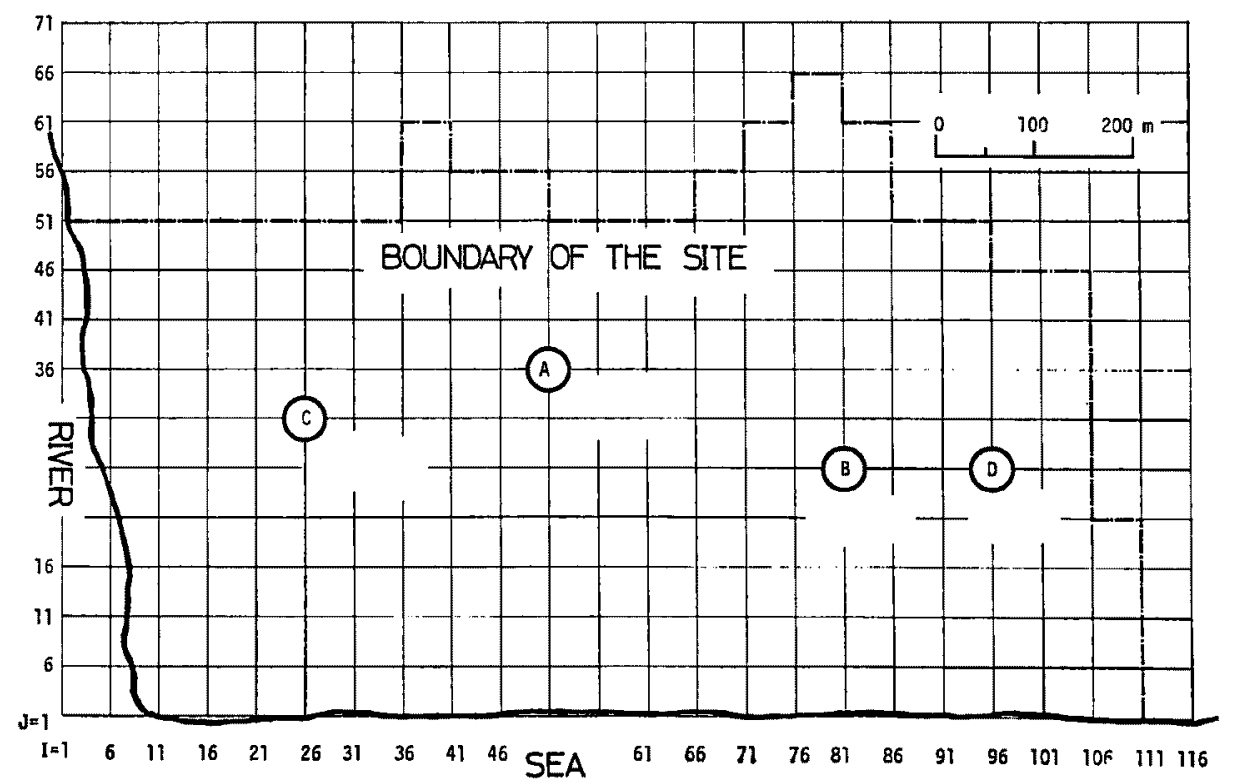

The node points A, B, C and D are estimated to be locally optimum locations for waste disposal sites from a radiological safety aspects ${ }^{(3)}$.

Fig. 1 Site of a nuclear facility where the ground disposal yard of radioactive waste is selected 
$\rho:$ 地層を構成する土㙴の密度

$f:$ 地下水層の空隚率 $k_{d}$ : 放射性核種の地下水と土埣々の間 の分配係数

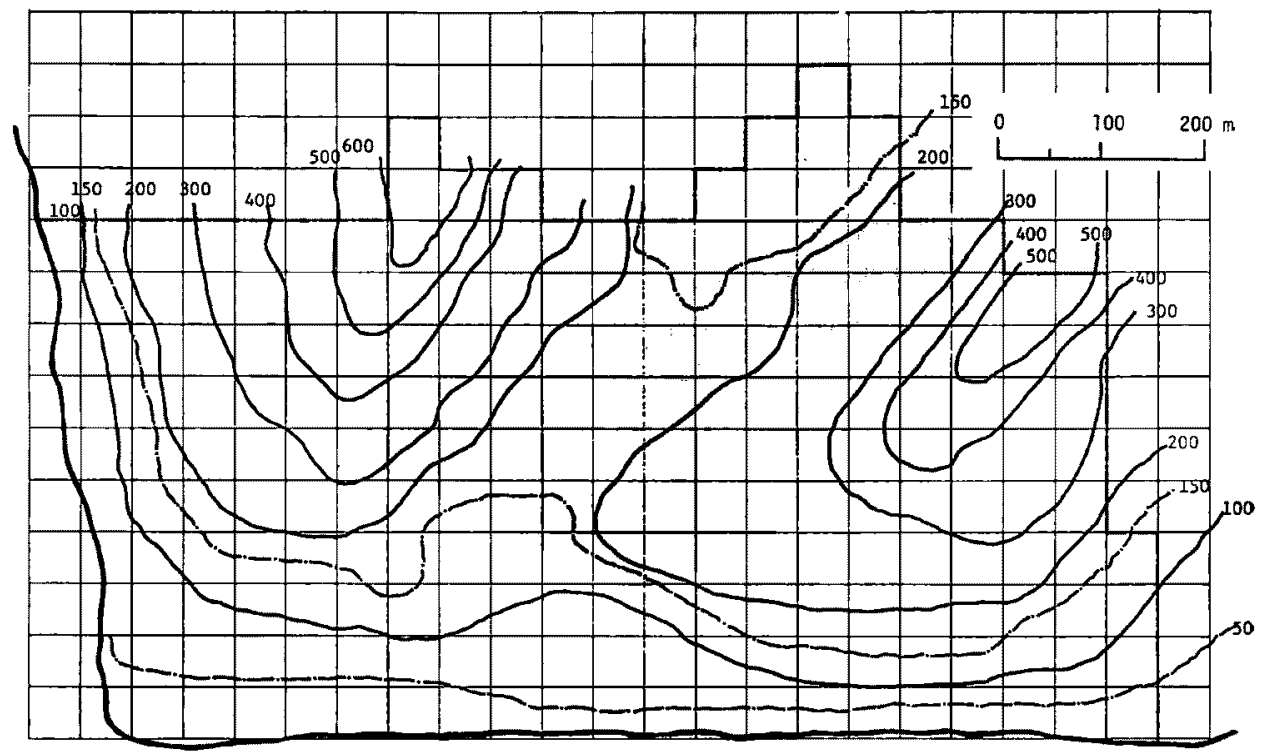

Numerical values in the figure are the groundwater level above a sea level in meter.

Fig. 2 Contour map of groundwater in the nuclear facility

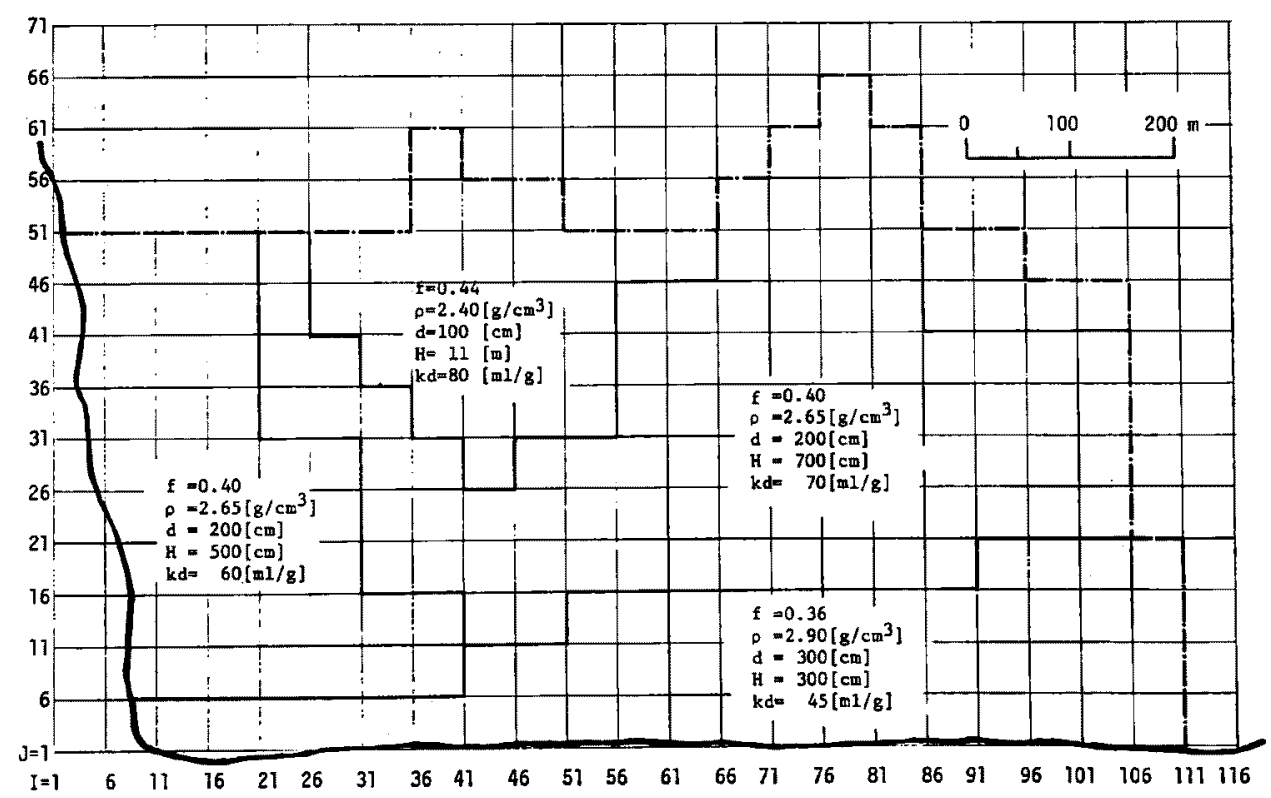

Fig. 3 Distribution of each environmental factor in the site which is required from determining a land requirement of waste disposal yard 
本報では地下水層の空陵率 $f$ が一定であると仮定して いる*はかは， $\rho, k_{d}, v_{x}, v_{y}, D_{x}, D_{y}$ は和のお。位置 $(x, y)$ の関数である。拡散係数 $D_{x}, D_{v}$ は打の沶の次 式で与党る(4)。

$$
\left\{\begin{array}{l}
D_{x}=D_{m}\left|v_{x}\right|+D_{d} \\
D_{y}=D_{m}\left|v_{y}\right|+D_{d}
\end{array}\right.
$$

ここに, $D_{m}$ : 標藩抬散係数(定数)

$D_{d}$ : 分子抬散保数(定数)

ここで，(2)式を(1)式へ代入し，さらに

$$
\frac{t}{T}=K_{f} \equiv 1+\frac{1-f}{f} \rho k_{c}
$$

なる变数変換を施す之，次式を得ることができる。

$$
\begin{aligned}
\frac{\partial C}{\partial T}= & \frac{\partial}{\partial x}\left(D_{\imath} \frac{\partial C}{\partial x}\right)+\frac{\partial}{\partial y}\left(D_{y} \frac{\partial C}{\partial y}\right) \\
& -\frac{\partial}{\partial x}\left(v_{x} C\right)-\frac{\partial}{\partial y}\left(v_{y} C\right)-\lambda K, C
\end{aligned}
$$

本報では，地下水中の放射性核種の濃度分布を推定す る基礎式として(5)式を用いる**。

\section{2. 数值解法}

基礎式(5)は解析的偟解くことができない。ここで は(5)式を Crank-Nicolson 型の差分近似をし，逐次 過緩和法 (SOR) によって数值的に解くことにする。 翰送項の差分については，設定した座標軸に対して流 速が正である場合には後進型の，負である場合には前 進型の差分を採用した。以下に $v_{x}, v_{\nu}$ がともに正の 場合の差分近似例を示す。

当該敷地を正方形格子網で覆い，位固 $(x, y)$ を格子 点 $(i, j)=(i \Delta x, j \Delta y)$ で表わす。格子点 $(i, j)$ に打 ける時刻 $n$ での地下水中核種濃度を $C_{n}^{n}$ 々すると， 時刻 $n+1$ での核種浱度 $C_{i, j}^{n+1}$ は次のよ5に与えられ る。

$$
\begin{aligned}
C_{i, j}^{n+1}= & C_{i, j}^{n}+\omega E_{i, j} \\
E_{i, j}= & \frac{1}{k+A}\left\{(k-A) C_{i, j}^{n}+B\left(C_{i+1, j}^{n+1}+C_{i+1, j}^{n}\right)\right. \\
& +D\left(C_{i-1, j}^{n+1}+C_{i-1, j}^{n}\right)+F\left(C_{i, j-1}^{n+1}+C_{i, j-1}^{n}\right) \\
& \left.+G\left(C_{i, j+1}^{n+1}+C_{i, j+1}^{n}\right)\right\}-C_{i, j}^{n+1}
\end{aligned}
$$

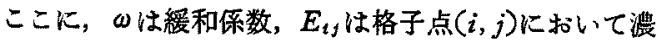
度を逐次計算する場合の補正量である。 $k, A, B, D, F$, $G$ は拉のおの差分近似汇関する保数で, 格子点 $(i, j)$ について次のように与方らる。

$$
\begin{aligned}
& k=(\Delta x)^{2} / \Delta t=(\Delta y)^{2} / \Delta t=a^{2} / \Delta t \\
& A=\frac{1}{2}\{ \lambda K_{f}+D_{x}(i+1 / 2, j)+D_{x}(i-1 / 2, j) \\
&+D_{v}(i, j+1 / 2)+D_{y}(i, j-1 / 2) \\
&\left.+a v_{x}(i-1 / 2, j)+a v_{v}(i, j-1 / 2)\right\}
\end{aligned}
$$

$$
\begin{aligned}
& B=\frac{1}{2} D_{x}(i+1 / 2, j) \\
& D=\frac{1}{2}\left\{D_{x}(i-1 / 2, j)+a v_{x}(i-1 / 2, j)\right\} \\
& F=\frac{1}{2}\left\{D_{y}(i, j-1 / 2)+a v_{y}(i, j-1 / 2)\right\} \\
& G=\frac{1}{2} D_{y}(i, j+1 / 2)
\end{aligned}
$$

設定した正方形格子網の境界では，地下水中の放射 性核種の濃度勾配が一定, すなわち $\partial^{2} C / \partial x^{2}=\partial^{2} C /$ $\partial y^{2}=0$ と仮定した。それゆ充，例えば設定した $x$ 軸 の右端境界格子点の核種濃度は次式で与えられる。

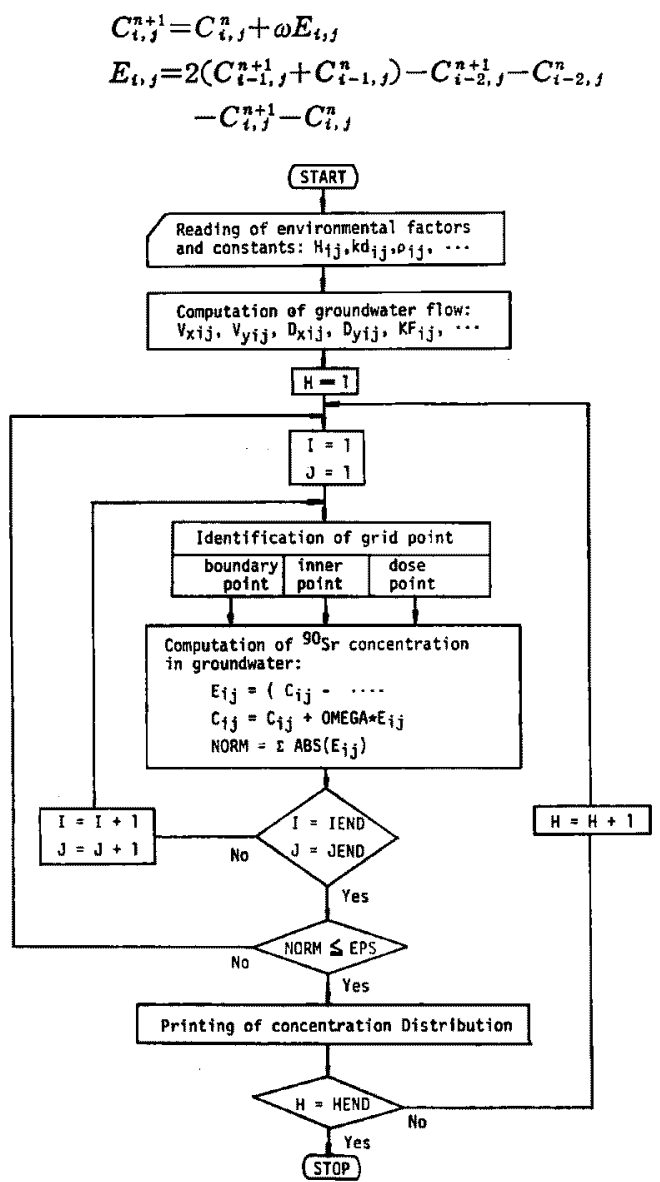

Fig. 4 Flow-chart of computation for estimating ${ }^{80} \mathrm{Sr}$ distribution in aquifer around the disposal yard

*本報で行 万解析において不可欠な仮定ではない。 式の変形が本報とは異なるが，他の環境因子と同 じく場所の関数として変化させることができる。

**（5）式によって，地下污染物留の䑳送・搪散を予 澌できる上万な地層か寒際に存在することが知ら れている(文献(5)参照)。 
核種濃度の初期条件は，処分開始時に処分場地下 の地下水を除き，すべての位直の核種濃度をぜロとし た。また，地中に処分した放射性固体廃棄物からは放 射性核種が定常的に一定速度で地下水中へ漏出すると 仮定し, 処分場直下の地下水中の核種濃度は常に一定 保たれるすのと想定した。

計算に用いたフロー・チャートをFig.4に示す。

\section{3. 鳝}

合計電気出力が $2,000 \mathrm{MWe}$ の原子力発電所の耐用 年数を20年とし, 同発電所から20年間に発生する放射 性廃棄物の全量をせメント固化し，容器に入れずに 1 度に地中に埋設すると，廃车物から地中へ稳行する1 年当りの放射性核種量は $2.17 \times 10^{4} \mathrm{Ci} ， 5 丂^{00} \mathrm{Sr}$ の占 わる放射能量は $1.68 \times 10^{3} \mathrm{Ci}$ であると推算されてい る(6)。廃棄物をセメント固化して地中妈分する場合に は，地中処分の安全性を支配する決定核種が ${ }^{80} \mathrm{Sr}$ 之 なる場合が多いから，ここでは地中へ移行する放射性 核種のらち特に ${ }^{90} \mathrm{~S} r$ に注目して検討する。想定した廃 萧物の埋設場(面積 $10,000 \mathrm{~m}^{2}$ ：Fig. 1 参照)において， 地中へ移行する ${ }^{90} \mathrm{Sr} 1.68 \times 10^{3} \mathrm{Ci} / \mathrm{yr}$ が埋設直下の地 下水增(厚さ $1 \mathrm{~m}$ とする)中で地下水によって一様に希 积され，しかるこの地下水中 ${ }^{\circ 0} \mathrm{Sr}$ 濃度は一定に保た れるるのとすると、この地下水中 ${ }^{90} \mathrm{Sr}$ 䀼度は

\section{$\frac{1.68 \times 10^{3} \mathrm{Ci}}{100 \mathrm{~m} \times 100 \mathrm{~m} \times 1 \mathrm{~m}}=1.68 \times 10^{-1} \mu \mathrm{Ci} / \mathrm{ml}$}

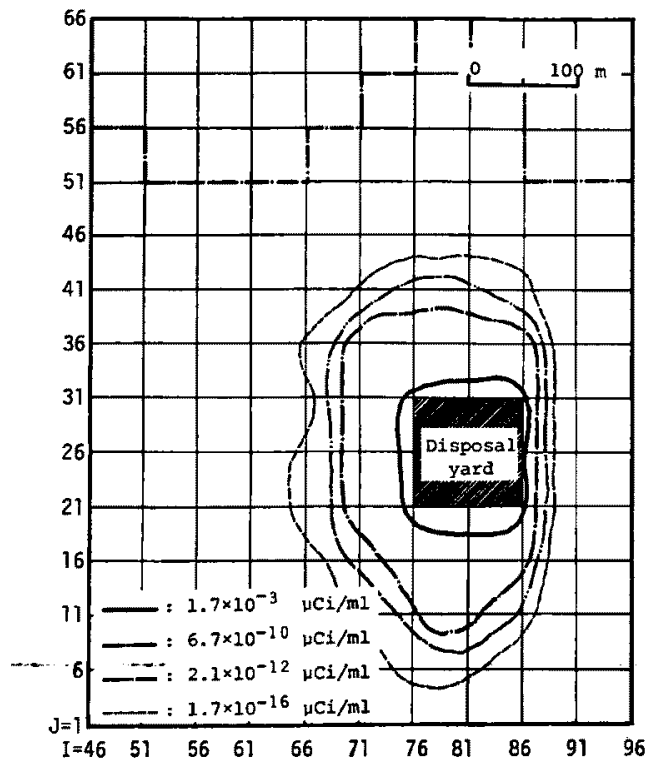

Fig. 5 Estimated distribution of ${ }^{90} \mathrm{Sr}$ in aquifer after $10 \mathrm{yr}$ of waste disposal operation
となる。

Fig. 3 で設定した環境因子以外の，計算に用いた環 境因子の值は次のとおりである。すなわち，標準拡散 俰数 $D_{m}=1.0 \mathrm{~cm}$, 分子拡散係数 $D_{d}=10^{-5} \mathrm{~cm}^{2} / \mathrm{sec}$, 地層の空箵率 $f=0.40$, 地圈の透水係数 $k_{s}=6.9 \times$ $10^{-2} \mathrm{~cm} / \mathrm{sec},{ }^{80} \mathrm{Sr}$ の半減期 $t_{1 / 2}=10^{4}$ 日である。

時間ステップ幅を0.05日, 空間ステップ幅を $\Delta x=$ $\Delta y=10 \mathrm{~m}$ として，すでに述べた数值解法によって計 算した ${ }^{90} \mathrm{Sr}$ の廃萧物理設場周辺地下水中の濃度分布 をFig. 5 およびFig. 6 に示す。Fig. 5 は10年後に期 待される ${ }^{\circ 0} \mathrm{~S}$ 地下水中濃度分布を，またFig. 6 は 海岸から $250 \mathrm{~m}$ 離れた格子線 $(j=26)$ 上の ${ }^{00} \mathrm{Sr}$ の地 下水中濃度の時間変化を図示したものである。処分 後，時間の経過とともに増加する立地要件を整理して Table 1 に示す。また，基礎式 ( 5 )の左辺をだ口と挔 いて定常解析することによって得た ${ }^{80} \mathrm{Sr}$ の地下水中 濃度の推定定常分布を Fig. 7 に示す。

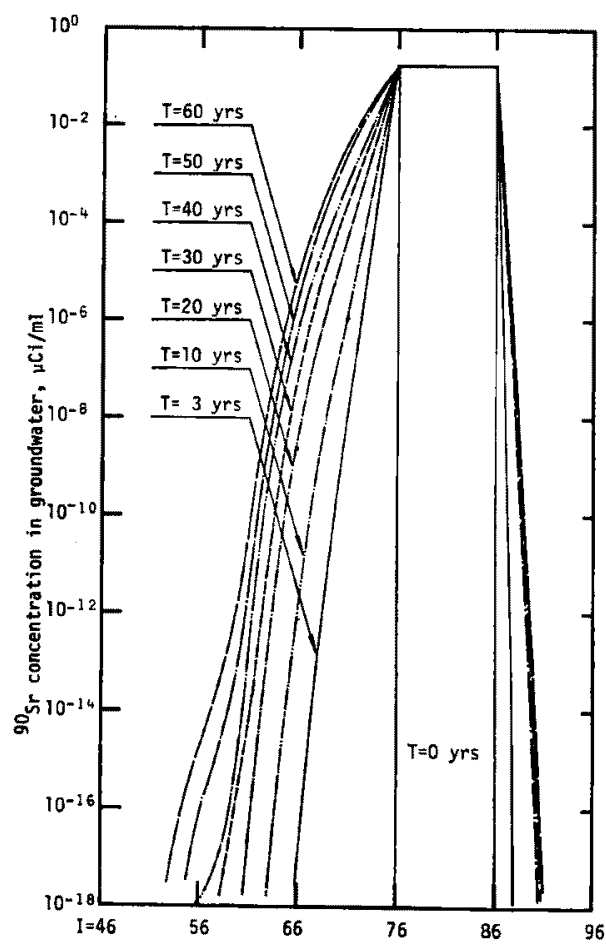

Numerical value $(T)$ in the figure means the time after waste disposal operation.

Fig. 6 Change of ${ }^{90} \mathrm{Sr}$ concentration in groundwater at $250 \mathrm{~m}$ apart from coastal line ( $J=26$ line) estimated through unsteady state analysis 
Table 1 Increase of land use restriction areas with increase of time estimated through an unsteady state analysis

\begin{tabular}{|c|c|c|}
\hline $\begin{array}{l}\text { Elapsed time } \\
\text { after waste } \\
\text { burial opera- } \\
\text { tion (yr) }\end{array}$ & $\begin{array}{l}\text { 1st restriction } \\
\text { area where } \\
\text { ground water use } \\
\text { should be } \\
\text { forbidden } \\
\qquad\left(\times 10^{4} \mathrm{~m}^{2}\right)\end{array}$ & $\begin{array}{l}\text { 2nd restriction } \\
\text { area }{ }^{\dagger} \text { where } \\
\text { groundwater use } \\
\text { for irrigation } \\
\text { should be } \\
\text { restricted } \\
\qquad\left(\times 10^{4} \mathrm{~m}^{2}\right)\end{array}$ \\
\hline 10 & 4.5 & 5.8 \\
\hline 20 & 6.3 & 8.0 \\
\hline 30 & 7.4 & 8.9 \\
\hline 40 & 8.1 & 10.0 \\
\hline 50 & 8.9 & 10.8 \\
\hline 60 & 9.5 & 11.2 \\
\hline $\begin{array}{c}\text { Infinite } \\
\text { (equilibrium) }\end{array}$ & 9.5 & 12.2 \\
\hline
\end{tabular}

+2 nd restriction area includes the lst restriction area and $10,000 \mathrm{~m}^{2}$ of waste burial yard.

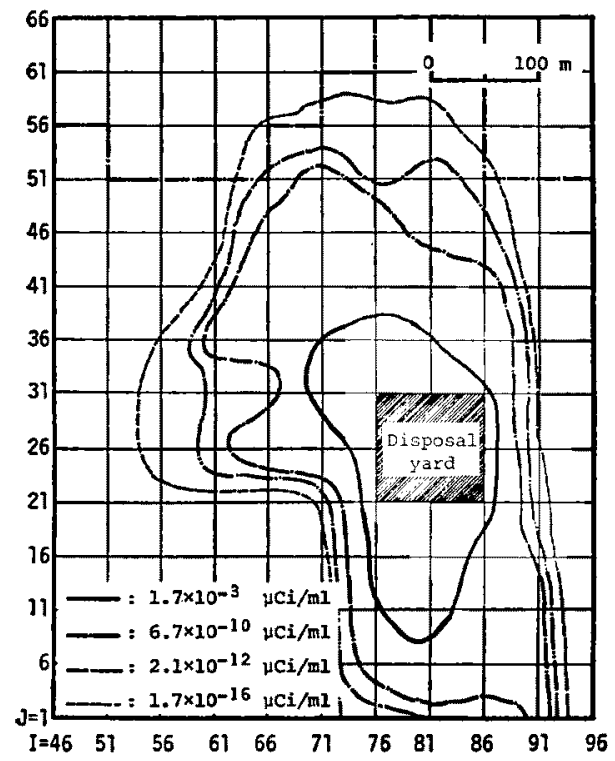

Each environmental factor has their standard value selected in this work (Refer to Table 2).

Fig. 7 Equilibrium ${ }^{00} \mathrm{Sr}$ distribution in aquifer estimated through steady state analysis

\section{III． 立地要件および土地利用の制限}

\section{1.土地利用の制限}

放射性核種を含む食物を摄取することによって，人 体が受ける内部波曝線量は次式を用いて推定すること
ができるすなかち、

地下水を飲用する場合

$$
D_{s}=D \frac{I_{d} C}{2200 M P C_{w}}
$$

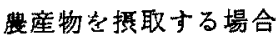

$$
D_{s}=D \frac{I_{p} C F_{p} k_{d} C}{2200 M P C_{w}}
$$

ここに, $D_{8}$ : 潜在的内部被曝線量の推定值

$D$ ：公䍃の構成買に対する線㽬限度

$M P C_{w}$ ：公賉の構成員に対する放射性核種の 飲料水中最大許容丧度

$I_{d}, I_{p}: お の お の$ 飲料水・豊産物の日提取量

$C$ ：放射性核種の地下水(灌溉水)中濃度

$C F_{p}$ ：费産物による放射性核種の灌縮係数

$k_{d}$ : 放射性核種の土壤への分配係数

本研究では，対象核種を ${ }^{80} \mathrm{Sr}$ に限って検討している から，(6)，(7)式中の各変数值は，公豙の構成員に 対して $M P C_{w}=4 \times 10^{-7} \mu \mathrm{Ci} / \mathrm{ml}, D=3 \mathrm{rem} / \mathrm{yr}^{(7)}, I_{d}$ $=2,200 \mathrm{ml} / \mathrm{day}, I_{p}=1,000 \mathrm{~g} / \mathrm{day}, C F_{p}=10^{*}, k_{d}=$ $70 \mathrm{ml} / \mathrm{g}$ となる。地中処分場周辺での人体の内部被懪 線量の限度值を公圌の構成員に対する線量限度の1/ 100,つまり $5 \mathrm{mrem} / \mathrm{yr}$ とすると，(6)式より地下水 中の ${ }^{90} \mathrm{Sr}$ の許容濃度は $6.7 \times 10^{-10} \mu \mathrm{Ci} / \mathrm{ml}$, (7)式よ り農産物の灌溉用水として用いる地下水中の ${ }^{\circ 0} \mathrm{Sr} の$ 許容濃度は $2.1 \times 10^{-12} \mu \mathrm{Ci} / \mathrm{ml}$ となる。

地下水および農産物を撕取することによって人体が 受ける潜在内部被曝線量を，許容線量限度内にとどあ るためには，Fig.5およびFig.7に执いて期待される

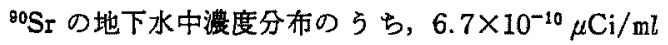
等濃度線で囲まれる区域では地下水の领用を禁止し， また $2.1 \times 10^{-12} \mu \mathrm{Ci} / \mathrm{ml}$ 等濃度線で囲まれる区域では 地下水を灌溉用水として利用することを禁止する必要

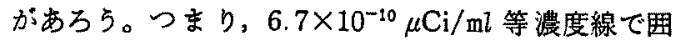
まれる区域を地下水の利用禁止区域， $6.7 \times 10^{-10} \mu \mathrm{Ci} /$ $\mathrm{ml}$ 等㴗度線と $2.1 \times 10^{-12} \mu \mathrm{Ci} / \mathrm{ml}$ 等濃度線とで讲まれ る区域を地下水の利用規制区域として，地下水を灌泊 用水として利用することを規制することになる。また 地下水の利用䙺制区域の外側に，濃度推定の䛊差，環 境特性值の測定埕差，規制措置の徹底不備等々による 規制区域設定の誤差を補らために，適切な濃度値を設 定して，安全を保障するための緩衝区域を設定するの

* 植物による核種の濃樎係数で，土燷中の核種濃度 $q(\mu \mathrm{Ci} / \mathrm{g})$ に対する植物中核種丵度 $q_{p}(\mu \mathrm{Ci} / \mathrm{g})$ の比の值 $q_{p} / q$ で定艇される。ここでは Menzel(日) の報告値を用いる。 
が有効であると思われる。この楥衝区域は，廃率物埋 設処分作業の開始後に行らモニタリング・データを用 いて次第に狭くしていくことができるであるう。放射 性廃棄物の埋設処分場は, この緩衝区域をも含めて, 地下水の利用規制区域・利用禁止区域の全体老の内 部に含さような敷地を確保すべさであると考える。

このような立地要件の設定には，将来にわたる安全 性を現段階で確保しておくために，定常解析に上る ${ }^{90} \mathrm{Sr}$ 濃度分布の推定値を用いることにする。

\section{2. 立地要件の変更}

前節で設定した廃莱物埋設場の立地要件は， ${ }^{90} \mathrm{Sr}$ 的 分布を推定するのに用いるモデルの種類，環境特性值 の変動, 测定誤差等のほか種々の因子によって変化す ると思われる。ここでは，立地要件の変化の原因とな る諾因子のらち環境要因(特に，抬散係数，透水係数，分 配係数扰よび地層の空谅率)に注目して, 立地要件が

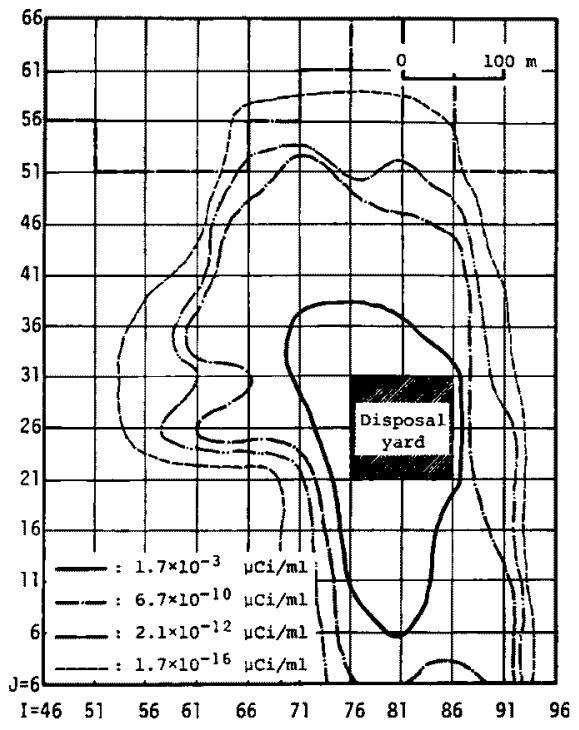

(a) Standard diffusion coeffiçient $D_{m}: 10 \mathrm{~cm}$

\section{どのように変化するかについて検討する。}

(1) 拡散係数 $D_{m}$

現実の地下水層に执いて搪散保数を実測した例は極 めてまれである。河川・湖沼・海洋等での抬散保数の実 測結果による之，その測定精度はほぼ 100\%つまり桩 散保数の実測は係数のオーダを定めるのが目的であ るとされている。ここでは，標準拡散係数 $D_{m} か ゙ 1.0$ $\mathrm{cm}$ の場合を標準例( Fig. 7 参照)として， $D_{m}$ が 10.0, $0.1 \mathrm{~cm}$ の場合について定常解析を行い, 得られた ${ }^{90} \mathrm{Sr}$ の地下水中濃度分布を和の括の Fig.8 (a)，(b)k示す。 Fig. 7 と Fig. 8(a), (b)を比較すると, ${ }^{90} \mathrm{Sr}$ の地下水中 浀度分布が淿とんど变化しないことがわかる。このこ とは，立地要件の設定に際しては地下水の拡散保数の 実測あるいは推定精度がオーダ推定を可能にする程度 でよいことを意味している。

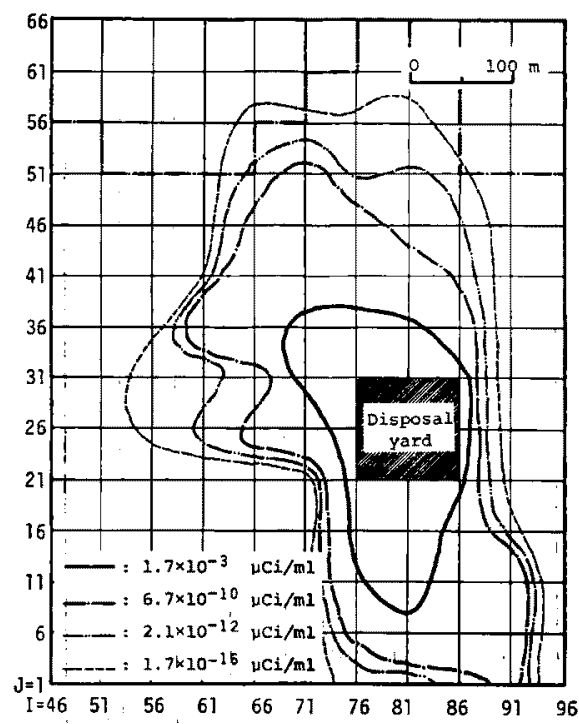

(b) Standard diffusion coefficient $D_{m}: 0.1 \mathrm{~cm}$

Fig. 8 Equilibrium ${ }^{\circ} \mathrm{Sr}$ distribution in aquifer

\section{（2）透水保数 $k$ 。}

地層の透水保数は，現場揚水試験等によって精度・信 頼度ともに比較的よく測定することができる。また， 水位のデータを用いて透水倸数の面的分布を推定する 方法も報告されている(9)。ここでは $k_{8} か ゙ 6.9 \times 10^{-2} \mathrm{~cm}$ $/ \sec$ の場合を標準例として，ks $10^{-2}, 6.9 \times 10^{-3} \mathrm{~cm} / \mathrm{sec}$ の場合について定常解析し た。透水㐿数が変化すれば地下水の流速が変化するた め，(3)式に從って扗散係数も変化する。地層の透水
係数が上記の值をとる場合の地下水利用禁止区域, 規 制区域の面積を整理してTable 2 と示す。同表を見る と，透水係数が変化することによって処分場の立地要 件がかなり変化することがわかる。地下水の利用規制 区域绣水係数の増加に伴って広くなる。透水保数は 比較的精度よく湘定することができるから，立地要 件の設定に際しては透水保数の測定個所を增すなどし て，透水俰数值の代表性・信頼性等を高めることが必 要であると思われる。本研究では，便宜上全數地的 
たって透水倸数は一定と仮定しているが，透水係数が 位眉によって变化するとしても解析には支障がない。

Table 2 Comparison of land use restriction area estimated numerically through a steady state analysis depending on each different environmental factor (Each restriction area is estimated supposing that only one environmental factor would deviate from the standard state)

\begin{tabular}{lrc}
\hline $\begin{array}{l}\text { Environmental } \\
\text { factor }\end{array}$ & $\begin{array}{l}\text { 1st restriction } \\
\text { area where } \\
\text { groundwater } \\
\text { use should be } \\
\text { forbidden } \\
\left(\times 10^{4} \mathrm{~m}^{2}\right)\end{array}$ & $\begin{array}{l}\text { 2nd restriction } \\
\text { area }{ }^{\dagger} \text { where } \\
\text { groundwater }\end{array}$ \\
$\begin{array}{l}\text { use for } \\
\text { irrigation } \\
\text { should be } \\
\text { restricted } \\
\left(\times 10^{4} \mathrm{~m}^{2}\right)\end{array}$ \\
\hline Standard†t & 9.5 & 12.2 \\
$f=0.3$ & 8.4 & 10.1 \\
$f=0.5$ & 10.1 & 13.4 \\
$k_{s}=6.9 \times 10^{-3} \mathrm{~cm} / \mathrm{sec}$ & 3.6 & 4.5 \\
$k_{s}=3.5 \times 10^{-2} \mathrm{~cm} / \mathrm{sec}$ & 7.3 & 9.1 \\
$k_{d}=1.4 \times 10^{-1} \mathrm{~cm} / \mathrm{sec}$ & 11.7 & 15.0 \\
$k_{d}=(25,30,35,40) \mathrm{m} l / \mathrm{g}$ & 11.8 & 14.6 \\
$k_{a}=(70,90,105,120) \mathrm{ml} / \mathrm{g}$ & 8.4 & 10.4 \\
\hline
\end{tabular}

1 2nd restriction area includes the 1 st restriction area and $10^{4} \mathrm{~m}^{2}$ of waste burial yard.

"It the standard state each environmental factor has a respective value, that is, porosity $f=0.4$, permeability coeff. $k_{s}=6.9 \times 10^{-2} \mathrm{~cm} / \mathrm{sec}$, distribution factor $k_{d}=(45,60$. $70.80) \mathrm{m} l / g$ (Refer to Fig. 3).

\section{（3） 分配保数 $k_{t}$}

放射性核種の分配保数值は地下水と土壤とを定めれ ば同一核䅜についてはほ注一定值となり，あまり変化 することはない。しかし，多量の廃率物を埋設したり すれば，特にセメント固化体等を埋設すると地下水中 の $\mathrm{Ca}, \mathrm{Mg}$ 等の共存イオン淟度が变化するため(5), 分配 係数值も変化するめ。ここでは，Fig.3で与光た分配 係数値を標準例として，分配係数值が 0.5 倍の場合と 1.5 倍の場合とについて定常解析した。おのおのの場 合の立地要件を整理してTable 2 亿示す。分配係数值 が変化することによって，立地要件がかなり变化する ことがわかる。地下水の利用規制区域は分配係数値の 增加沉伴って狭くなる。

(4) 地層の空隚率 $f$

地下水層の空隚率を直接に串測することは非常に困 難である。通常は透水俰数を実測する場合の揚水試験 飞よって得られる水位変化のデータから計算によって
推定したりあるいは空吵率を透水倸数に加味させた 有効透水係数を用いたりする。地層の透水係数はあま り広範围には変動することがない。ここでは, 空吵率 が0.40の場合を標準例として( Fig. 7 参照)，空隙率が 0.50，0.30の場合について定常解析した。得られた立 地要件を整理してTable 2 に示す。同表をみると，架 隚率が大きくなるほど地下水の规制区域む広くなるこ とがわかる。

ここで検討した以外の因子，例えば食習慣に関する 因子, 処分場周辺の人口分布に関する因子，さらに環 境因子のうらでも気候·天候汇関する因子, 水理・地質 的因子等々多くの因子によ。て処分場の立地要件は変 るすのと考兄られる。しかしながら，処分場の位置を 設定した後では, 環境因子のうちでは, 上で検討した 因子が特に大きな影響をるつるのと考えられる。地下 水を利用するために多量の地下水を汲み上げたりする 場合には，井戸の設瞋位值が規制区域の外側であって も，地下水の流線網が变化してしまう場合が多いか ら，規制区域の設定が妥当であるか否かを再倹討する 必要がある。本研究では，䔲棄物の埋設処分場は，あ らかしめ実施された安全性の検討飞招いて，放射性物 質が環境中へ漏出してる安全性を確保する上で望省し いとされた位置泣地させられるとした。検討した条 件下では，環境因子がどのような值をとる場合でも， 地下水の利用規制区域が敷地の外側にまで及ぱないよ らに選定されていた。規制区域が敷地の外唄にまで及 占場合には，數地面積を增加させる，処分場の立地位 置を変更する，処分量を減少させる，処分の方式を変 更する，あるいは処分環境を改善する等の対策が必要 になる。また， ${ }^{90} \mathrm{Sr}$ 以外の核種が決定核種になる場合 には，他の核種について同様の检討を実施する必要が ある。

\section{IN. 結 論}

地中に処分した放射性㾔率物に由来する放射性物質 によって受けると考えられる潜在的放射線障害が小さ くなる位置に立地した想定の廃棄物埋設処分場を例比 用いて，地下水中の ${ }^{\circ 0} \mathrm{Sr}$ 濃度分布に注目して処分場 の立地要件を定める考え方とその方法について恰討し

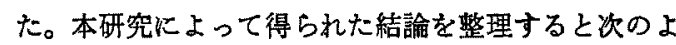
らになる。な和，本研究の計算には京都大学大型計算 機センターの FACOM 230-75を用いた。

(1) 本研究で検討した方法によれば，実用に際して は設定した仮定等についてさらに吟味を深める必 要はあるものの, 放射性廃棄物地中処分場の立地 
要件，つまり放射線学的安全を確保する上に必要 な処分場の必要面皘を合理的に設定することがで きる。

（2）放射性㲥亲物の地中処分場を安全に立地させる ためには，処分場の周囲に，地下水の利用禁止区 域，利用規制区域(地下水灌㳊用水として利用す ることの規制)および楥重区域を設定して，これ らの区域が処分場の敷地内に含まれるようにする ことが望ましい。

（3）放射性廃棄物地中処分場の立地要件は種々の条 件によって変化する。本研究で検討しな謤境因子 については，透水保数が大き，分配保数が小さ く，地層の空㗂率が大きいま之，地中処分場の立 地に必要な敷地面皘(立地要件)は大きくなる。地 下水の拡散保数の変化は立地要件の変化にあまり 大きな影響を及ぼさない。

（4）本研究で設定した条件，処分場の立地場所等の 下では，地下水利用の規制区域は注設定された
敷地内に含まれている。地下水利用の規制区域が 敷地内に含まれない場合には，敷地の払張; 工学 的防護処置の施工等の対策が必要になる。

\section{一巻考文献一}

（1）原子力委員会：原子炉立地蕃查指針拈よびその適用に関 する判断のめやすについて，38原委第99-(2)号，(1964).

(2) 井上頼輝, 森澤真輔: 本 誌, 14[12]，652 660 (1972).

(3) 同 上: 同上, 15[2], 126 135 (1973).

(4) AhLsT'Rom, S.W., et al.: $B N W L-1717$, (1974).

（5）井上頼輝，他：土木学会第 11 回徫生工学研究討論会論文 集, 47 52 (1975).

(9) Inoue, Y., Morisawa, S.: Health. Phys., 26[1], 53 63 (1974).

（7） ICRP：“体内放射線の許容線量”，(1959)，日本フイン トープ協会訳.

(8) MenzeL, R.G.: Health Phys., 11, 1325 1332 (1965).

(9) Nelson, R.W., et al.: "Transient Energy Dissipation Methods of Measuring Permeability Distributions in Unconfined Heterogeneous Porous $\mathrm{Ma}$ terials", (1972), Computer Sciences Co., U.S.A.

(10) 井上頼輝, 森澤真輔：本誌，揭載予定.

\begin{tabular}{|c|c|}
\hline 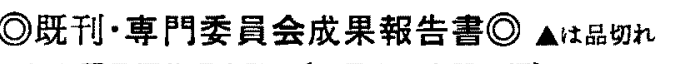 & 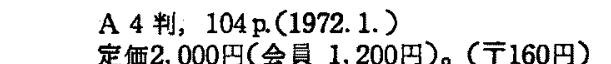 \\
\hline 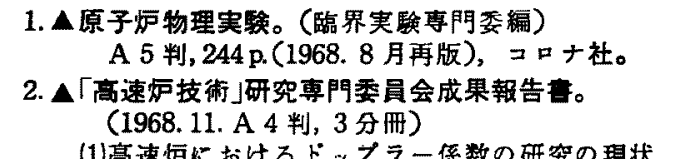 & 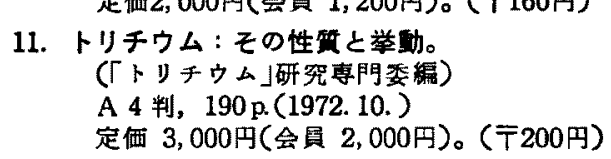 \\
\hline $\begin{array}{l}\text { (2)高速炬燃料のスウェリンク研究の現状. } \\
\text { (3)高速炬用液体 } \mathrm{Na} \text { 找街の基整 }\end{array}$ & $\begin{array}{l}\text { 12. А高速炉用燃料集合体の流動伝熱に関する } \\
\text { 調查研究。 }\end{array}$ \\
\hline 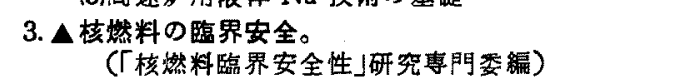 & $\begin{array}{l}\text { (「赢速邩 } \mathrm{Na} \text { 技術」特別專門委編) } \\
\mathrm{A} 4 \text { 判, } 436 \text { p. (1972.6.) }\end{array}$ \\
\hline 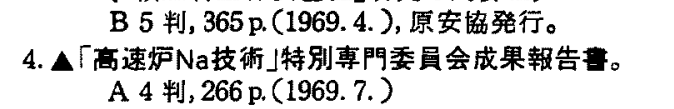 & 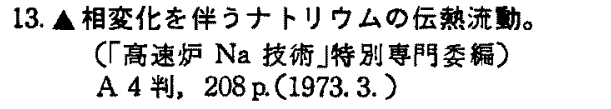 \\
\hline 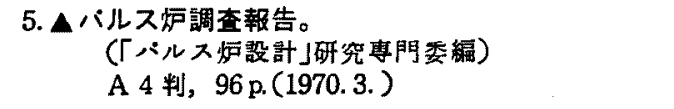 & 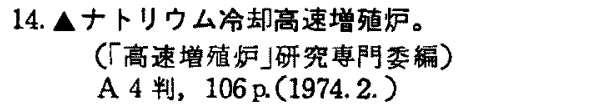 \\
\hline 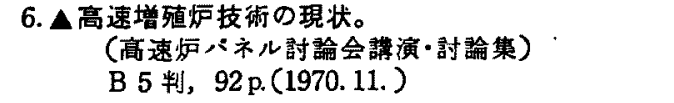 & 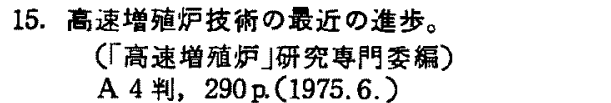 \\
\hline 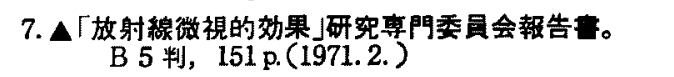 & 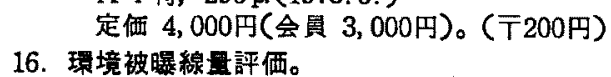 \\
\hline 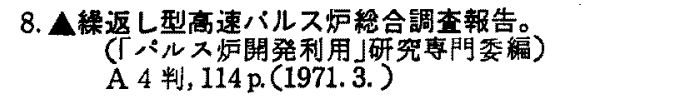 & 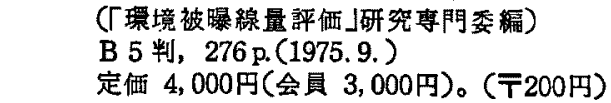 \\
\hline 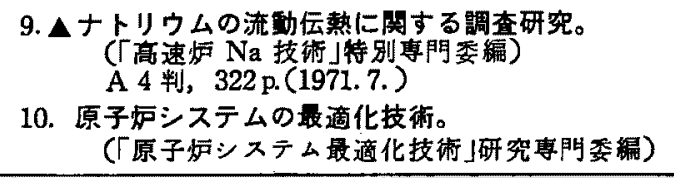 & 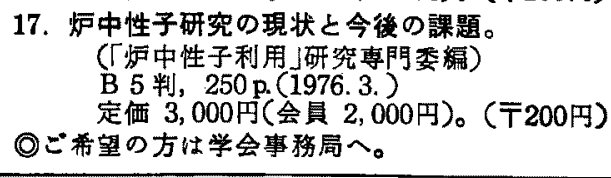 \\
\hline
\end{tabular}

